Jahangirnagar University J. Biol. Sci. 8(1): 25-33, 2019 (June)

\title{
Proximate composition of two puffer fish species, Leiodon cutcutia and Dichotomyctere fluviatilis of Bangladesh
}

\author{
Ishtiak Ahmed Chowdhury, Md. Rakibul Hasan ${ }^{1}$, Suraiya Parveen ${ }^{1}$, Shuvra Kanti \\ Dey $^{2}$ and Md. Baki Billah* \\ Department of Zoology, Jahangirnagar University, Savar, Dhaka-1342, Bangladesh
}

\begin{abstract}
Protein, lipid, ash and moisture content in the body muscles of two commonly available puffer fish species in Bangladesh (Leiodon cutcutia and Dichtomyctere fluviatilis) have been analysed from January 2018 to June, 2018. The puffer fish species were collected from different habitats i.e., Leiodon cutcutia from freshwater and Dichtomyctere fluviatilis from estuarine water. The percentage of the proximate composition varied in different months in both the species. In Leiodon cutcutia, moisture content fluctuated from $79.32 \%$ to $87.61 \%$ with an average of $83.75 \%$; protein content from $6.35 \%$ to $13.31 \%$ with an average of $9.49 \%$; lipid content from $1.57 \%$ to $2.32 \%$ with an average of $1.92 \%$ and ash content from $2.30 \%$ to $3.27 \%$ with an average of $2.84 \%$. In Dichotomyctere fluviatilis, moisture content fluctuated from $73.77 \%$ to $84.18 \%$ with an average of $77.49 \%$; protein content from $10.03 \%$ to $19.77 \%$ with an average of $16.80 \%$; lipid content from $0.92 \%$ to $1.71 \%$ with an average of $1.32 \%$ and ash content from $2.77 \%$ to $3.34 \%$ with an average of $3.05 \%$. The comparative evaluation of the nutritional value of the studied fish species revealed that the puffer fish from estuarine environment might contain higher amount of nutrients. Thus, proper utilization of this species towards sustainable management, nutritional composition and biosecurity issues will lead to achieve sustainable blue economy.
\end{abstract}

Key words: Puffer fish, proximate composition, Bangladesh

\section{INTRODUCTION}

Bangladesh has huge potentials in terms of diverse marine fauna and is considered one of the most suitable regions for fisheries in the world, with the world's largest flooded wetland and the third largest aquatic biodiversity in Asia after China and India (Shamsuzzaman et al., 2017).

Puffer fish (Patka mach) is a balloon-shaped fish of the family Leiodontidae, order Leiodontiformes. The fish is able to inflate itself enormously with air like a balloon, and are found both in freshwater and marine environments. Among the puffer fish species, three species under two genera are commonly available in Bangladesh. Among them, Leiodon cutcutia has broad head and back, tapering abruptly at the tail. Upper part of the body is greenish yellow, abdomen white, body length is about $3 \mathrm{~cm}$. The fish is found widely in the freshwater throughout the country. On the other hand, Dichotomyctere fluviatilis is slightly compressed bodied attains a length of about $12 \mathrm{~cm}$ with broad head

\footnotetext{
${ }^{1}$ Biological Research Division, Zoology Section, BCSIR, Dhaka-1205, Bangladesh

${ }^{2}$ Department of Microbiology, Jahangirnagar University, Savar, Dhaka-1342, Bangladesh

* Corresponding author. Email: bakibillah29@gmail.com
} 
and back, tapering abruptly to tail. Upper part of the body is olive green; sides and lower part white; there are black blotches on the back and sides. The fish is found in rivers and estuaries (Santini et al., 2013).

Proximate composition is well known as a proportion of the composition of basic elements such as protein, lipids (fats and oils), carbohydrate, minerals (ash) and water (moisture). The percentage of the composition of four major constituents of fish viz., moisture, protein, lipid and ash (minerals) account for about $96-98 \%$ of total tissue in most fish (Azman et al., 2015). Though puffer fish is eaten in some places in the southern districts after cooking in a special way, the fish has poisonous effects, and occasional deaths have been reported (Islam et al., 2018). Dichotomyctere fluviatilis can be ideally used for meeting the demand of fish protein and Leiodon cucutia can be utilized as an alternative source which can help in the increasing demand of fish with the increasing population. They can also be utilized as fish feeds and poultry feeds.

There are special chefs for preparing this delicious fish in Japan where the fish is consumed as delicatessen and expensive food item. The skill for preparing the fish is crucial as any deviation can lead to serious poisoning with neuro-paralysis and potential death (Islam et al., 2018).It has been reported that almost all puffer fish contain tetrodotoxin (TTX), a substance that makes them foul tasting and often lethal to other fish. To human, TTX is deadly, up to 1,200 times more poisonous than cyanide. Despite the risk of being intoxicated, puffer fish are being used as food to meet the nutritional requirements of increasing population by many Asian countries (Eswar et al., 2014).

But the information on the proximate composition of available puffer fish species in Bangladesh is still insufficient. Moreover, the nutritional data on marine puffer fish is scare. Therefore, the aim of our study was to compare the proximate profile of two puffer species from different habitats for determining their nutritional values and suitability as protein source.

\section{MATERIALS AND METHODS}

Collection of fish: The fishes, Leiodon cuctcutia $(4 \pm 1.2 \mathrm{~cm})$ and Dichotomyctere fluviatilis $(15 \pm 3.1 \mathrm{~cm})$ were collected from fish landing station of Cox's Bazar. A total 24 samples were collected and kept in the ice box and transported to the Biological Research Division, Zoology Section, Bangladesh Council of Scientific and Industrial Research (BCSIR) laboratory for investigation. The study was carried out for six months from January 2018 to June 2018.

Sample preparation: The raw fish samples were collected in irradiated polybags and kept at $4^{\circ} \mathrm{C}$. Before analysis samples were washed properly and then head, skin, fins, viscera and bones were cut off to separate the edible muscle portion. The fish muscles were taken as much as possible and the two types of puffer muscles were kept separately. Then the muscles were homogenized by cutting into small pieces using scissor. After this, the samples were prepared for the proximate analysis (Nandeesha et al., 1998). 
Determination of moisture content: Moisture of fish is commonly determined by "Oven Drying Method" of AOAC (1975). $10 \mathrm{~g}$ of fairly minced fish muscles was taken in a preweighted crucible and dried at about $100-105^{\circ} \mathrm{C}$ in an oven for 5-6 hours. Then it was cooled in desiccator and weighted. The weight difference between fresh and dry sample gave the moisture content.

Moisture content $(\%)=\frac{\text { Wet weight of the sample }- \text { Dry weight f the sample }}{\text { Weight of the sample }} \times 100$

Determination of protein content: For determining the protein content of fish muscle, at first total nitrogen of crude protein in fish muscle was determined by the universally accepted "Micro-Kjeldahl" method. At first, $1 \mathrm{~g}$ minced sample of fish muscle was taken in a filter paper and then transferred into a digestion apparatus flask. For Blank, only filter paper was taken without sample. Then each of two samples was digested with $2 \mathrm{~g}$ digestion mixture (98 parts of anhydrous $\mathrm{K}_{2} \mathrm{SO}_{4}$ is mixed with 2 parts of $\mathrm{CuSO}_{4}$ ) and 25 $\mathrm{ml}$ conc. sulfuric acid and heated at $315^{\circ} \mathrm{C}$ for 5-6 hours until the mixture became clear. The digested products were cooled and transferred into a $100 \mathrm{ml}$ volumetric flask and volume up to $100 \mathrm{ml}$ with distilled water. From this dilute solution, $5 \mathrm{ml}$ was taken with $10 \mathrm{ml}$ of $30 \% \mathrm{NaOH}$ and $100 \mathrm{ml}$ of distilled water and then was transferred to distillation chamber. The distillate was collected in a $100 \mathrm{ml}$ volumetric flask with $10 \mathrm{ml}$ of $2 \%$ boric acid and 4 drops of phenolphthalein indicator. The solution was titrated adding $0.01 \mathrm{~N}$ $\mathrm{HCl}$ drop wise from burette until a faint pink color appears. A similar digestion and titration was also carried out without samples (for blank).

Nitrogen content $(\%)=\begin{gathered}(S-B) \times N \times 14.007 \times C \\ A \times W\end{gathered} \times 100$

Where, $\mathrm{S}=$ Titration reading for sample, $\mathrm{B}=$ Titration reading for blank, $\mathrm{N}=$ Strength of $\mathrm{HCl}$ $(0.01 \mathrm{~N}), \mathrm{C}=$ Volume made up to digest $(100 \mathrm{ml}), \mathrm{A}=$ Aliquots of digest taken, $\mathrm{W}=\mathrm{Weight}$ of the sample. Now, protein content $(\%)=$ Nitrogen content $(\%) \times 6.25$

Determination of lipid content: The lipid content of fish was determined using the method described by Folch et al. (1957). At first, $5 \mathrm{~g}$ of fish muscle was taken in a mortar and homogenized properly with some sand by pestle. Then $10 \mathrm{ml}$ of chloroform-methanol mixture (2:1) was added into the mortar and homogenized properly. The homogenized solution was then filtered through a filter paper and collected into a pre-weighted test tube. Now $1 \mathrm{ml}$ of $4 \% \mathrm{CaCl}_{2}$ solution was added in the test tube and kept it overnight. The supernatant from the the test tube was removed and the solid extract was heated in oven until the mixture was dried. The difference between final and initial weight of test tube gave the weight of the lipid content.

Lipid Content $(\%)=\frac{(\text { Final weight }- \text { Initial weight) of the test tube }}{\text { Weight of the sample taken }} \times 100$ 
Determination of ash content: Ash content of fish muscle was determined by the "Gravimetric Method" (AOAC method). 5gm of raw fish muscle was taken in a crucible and kept in the muffle-furnace at $550^{\circ} \mathrm{C}$ for 16 hours. After full combustion, the crucibles were cooled in desiccator and re-weighted. The difference of the weight of the crucibles after and before combustion gave the weight of ash content.

Ash Conlent (\%) $-\frac{A-B}{C} \times 100$

Where, $\mathrm{A}=$ Weight of crucible with raw sample, $\mathrm{B}=$ Weight of crucible with combusted sample, $\mathrm{C}=$ Weight of the sample.

Statistical analysis: All the nutrient parameters were tested using one-way analysis of variance (ANOVA). Significant results $(\mathrm{p}<0.05)$ were further tested using Duncan's Multiple Range Test (DMRT) with the aid of the computer software SPSS 17.0 program.

\section{RESULTS AND DISCUSSION}

Average percentage of proximate contents: The average or mean value of moisture, protein, lipid and ash content in the body muscles of Leiodon cutcutia were $83.75 \%$, $9.49 \%, 1.92 \%$ and $2.84 \%$ respectively. In Dichotomyctere fluviatilis, the average or mean value of moisture, protein, lipid and ash content were $77.49 \%, 16.80 \%, 1.32 \%$ and $3.05 \%$ respectively (Table 1).

Table 1. Average percentage ( \pm SD) of moisture, protein, lipid and ash content in the body muscles of Leiodon cutcutia and Dichotomyctere fluviatilis

\begin{tabular}{c|c|c}
\hline Proximate content (\%) & Leiodon cutcutia & Dichotomyctere fluviatilis \\
\hline Moisture & $83.75 \pm 2.88$ & $77.49 \pm 3.86$ \\
Protein & $9.49 \pm 2.57$ & $16.80 \pm 3.52$ \\
Lipid & $1.92 \pm 0.271$ & $1.32 \pm 0.299$ \\
Ash & $2.84 \pm 0.398$ & $3.05 \pm 0.196$ \\
\hline
\end{tabular}

Moisture content: The percentage of moisture content in fish muscle fluctuated from $79.32 \%$ to $87.61 \%$ in case of Leiodon cutcutia and from $73.77 \%$ to $84.18 \%$ in case of Dichotomyctere fluviatilis. The average of the moisture content was $83.75 \%$ in Leiodon cutcutia and $77.49 \%$ in Dichotomyctere fluviatilis. The highest and lowest value was found in the month of April and February respectively in Leiodon cutcutia and whereas in Dichotomyctere fluviatilis it was in the month of February and March respectively (Fig.1). 


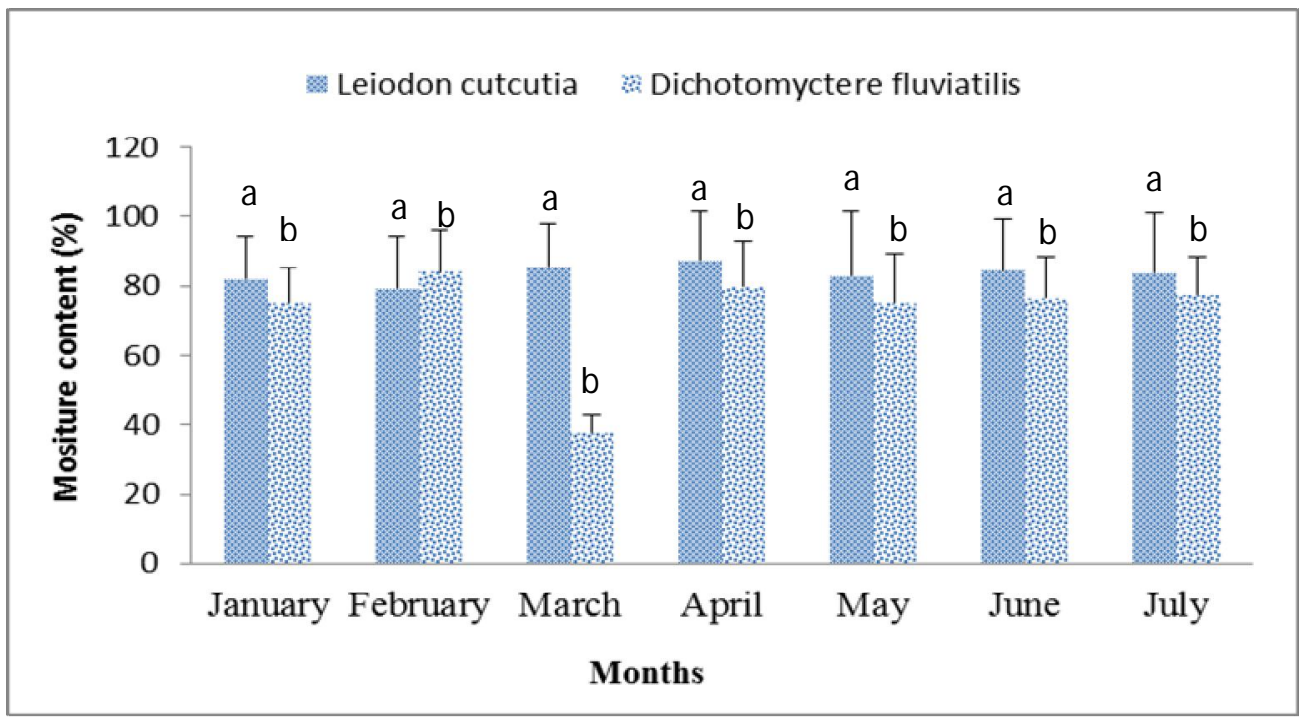

Fig. 1. Monthly variations of moisture content $(\%)$ in the body muscle of Leiodon cutcutia and Dichotomyctere fluviatilis. Bar with different letters represents significant differences of the moisture content of the two puffer fish species in different months (one way ANOVA followed by Duncan test, $p<0.05$ )

Leiodon cutcutia has got significantly higher $(\mathrm{p}>0.05)$ moisture content than that of Dichotomyctere fluviatilis. Ray et al. (2014) stated that the moisture content of Leiodon cutcutia ranges from about 66.52-82.28\%. Eswar et al. (2014) worked with Legocephalus inermis and Legocephalus lunaris and showed that it contains about $86.05 \%$ and $80.32 \%$ moisture in the proximate composition respectively.

Protein content: The percentage protein content in the fish muscle fluctuated from $6.35 \%$ to $13.31 \%$ in case of Leiodon cutcutia and from $10.03 \%$ to $19.77 \%$ in case of Dichotomyctere fluviatilis. The mean value or average of the protein content was $9.49 \%$ in Leiodon cutcutia and $16.80 \%$ in Dichotomyctere fluviatilis. The highest and lowest value was found in the month of February and March respectively in Leiodon cutcutia and in case of Dichotomyctere fluviatilis it was in the month of February and May respectively (Fig. 2). 


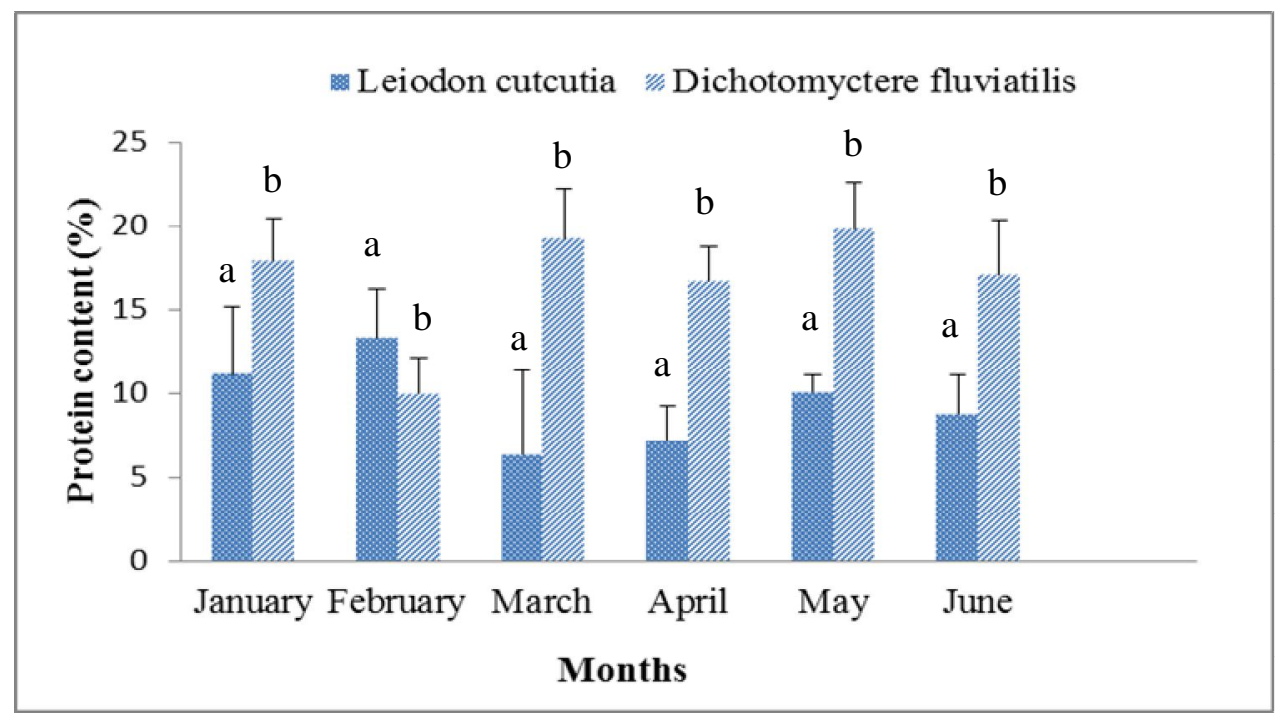

Fig. 2. Monthly variations of protein content $(\%)$ in the body muscle of Leiodon cutcutia and Dichotomyctere fluviatilis. Values with different superscripts represent significant differences among the different months of the protein content of the two puffer fish species (one way ANOVA followed by Duncan test, $p<0.05$ )

In Leiodon cutcutia, the percentage of protein content is significantly ( $>>0.05)$ less than Dichotomyctere fluviatilis. Therefore, from the nutritional point of view, Dichotomyctere fluviatilis is more acceptable than Leiodon cutcutia as a diet. Ray et al. (2014) showed in their study that Leiodon cutcutia contains about $17.21 \%$ protein in the body composition. Yuqi et al. (2014) showed that different body parts of Leiodon cutcutia contain about 15.62-23.45\% protein in the body composition. Eswar et al. (2014) showed in their research that Legocephalus lunaris and Legocephalus inurmis contain about $9.22 \%$ and $8.92 \%$ protein respectively in the proximate composition.

Lipid content: The percentage of lipid content in the fish muscle fluctuated from $1.57 \%$ to $2.32 \%$ in case of Leiodon cutcutia and from $0.92 \%$ to $1.71 \%$ in case of Dichotomyctere fluviatilis. The mean value or average of the lipid content was $1.92 \%$ in Leiodon cutcutia and $1.32 \%$ in Dichotomyctere fluviatilis. The highest and lowest value was found in the month of February and April respectively in Leiodon cutcutia and in case of Dichotomyctere fluviatilis it was in the month of January and April respectively (Fig. 3). 


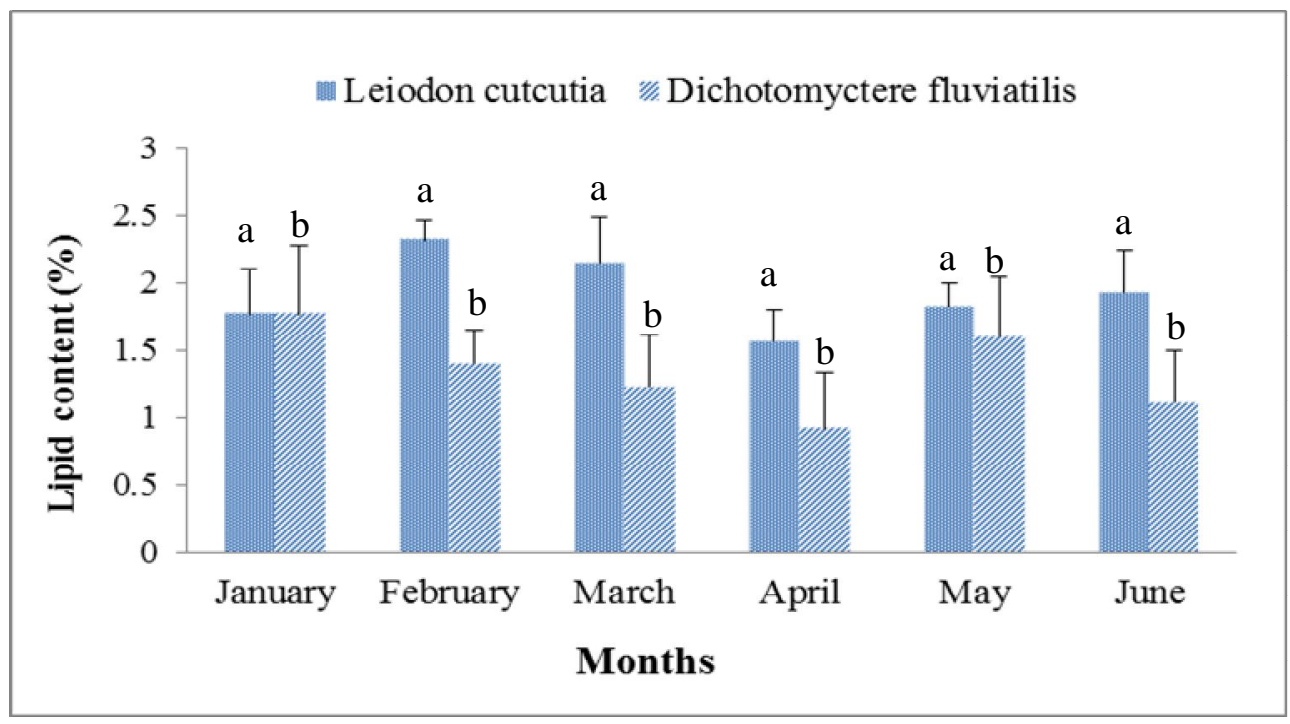

Fig. 3. Monthly variations of lipid content $(\%)$ in the body muscle of Leiodon cutcutia and Dichotomyctere fluviatilis. Bar with different letters represents significant differences among the different months of the lipid content of the two puffer fish species (one way ANOVA followed by Duncan test, $p<0.05$ )

Therefore, both species of puffer have acceptable amount of lipid as suggested by FAO to be taken as diet like other edible fishes. While removing skin, viscera and gut contents, and even head oil or oil like sticky substances were found, especially from Leiodon cutcutia. Yuqi et al. (2014) concluded that remarkably, the puffer fish- Leiodon cutcutia contains significantly higher amount of oil (21-49\%) and protein (16-23\%). Eswar et al. (2014) stated that two shallow water coastal puffer fish species Legocephalus lunaris and Legocephalus inermis contain about $11.25 \%$ and $11.98 \%$ lipid content in the proximate composition respectively.

Ash content: The percentage of ash content in the fish muscle fluctuated from $2.30 \%$ to $3.27 \%$ in case of Leiodon cutcutia and from $2.77 \%$ to $3.34 \%$ in case of Dichotomyctere fluviatilis. The mean value or average of the ash content was $2.84 \%$ in Leiodon cutcutia and 3.05\% in Dichotomyctere fluviatilis. The highest and lowest value was found in the month of March and April respectively in Leiodon cutcutia and in Dichotomyctere fluviatilis it was in the month of March and February respectively (Fig. 4). 


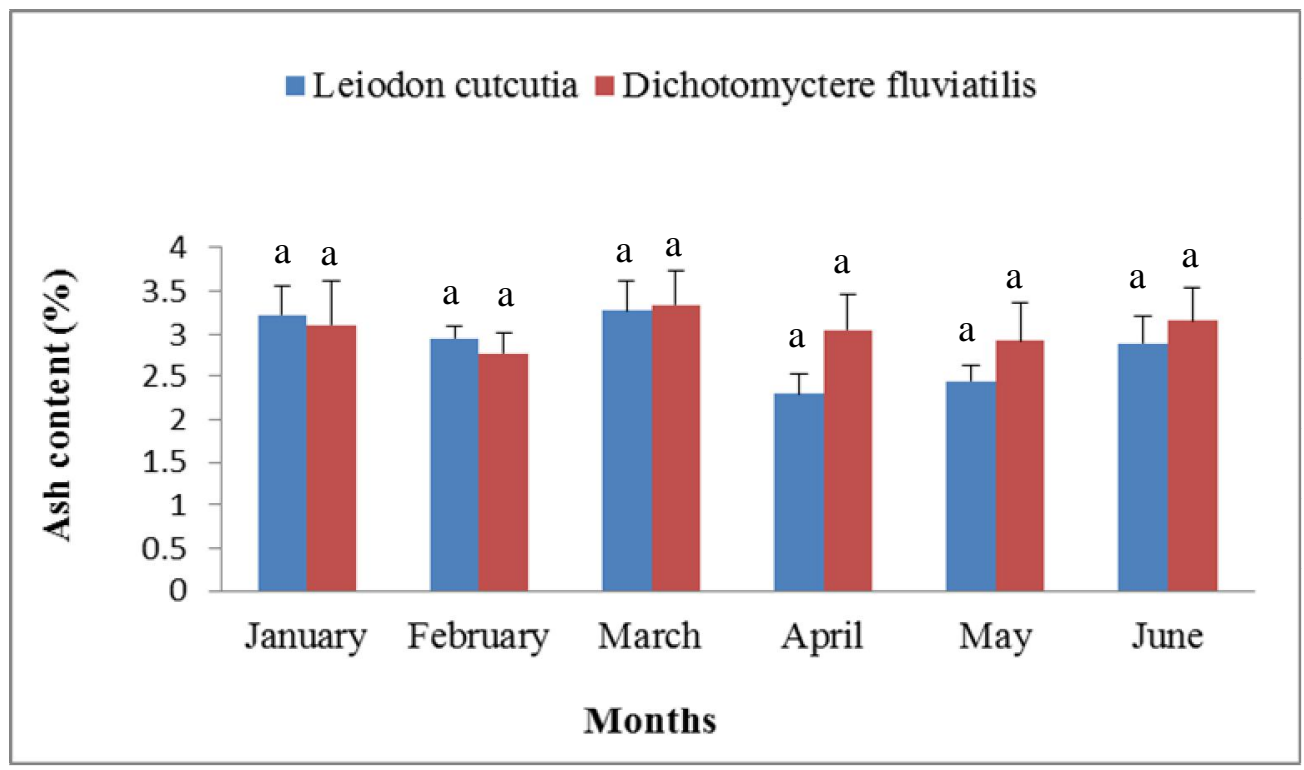

Fig. 4. Monthly variations of ash content (\%) in the body muscle of Leiodon cutcutia and Dichotomyctere fluviatilis. Bar with similar letters represents no significant differences in ash content of the two puffer fish species in different months (one way ANOVA followed by Duncan test, $p<0.05$ )

The amount of ash content indicates that both species of puffer contain minerals that are significant as human nutrition. Ray et al. (2014) showed that the ash content of Leiodon cutcutia ranges from $2.14 \%$ to $6.67 \%$ in the body's biochemical composition. Eswar et al. (2014) stated that Legocephalus lunaris and Legocephalus inermis, two coastal puffer species, contain about $0.96 \%$ and $1.27 \%$ ash content in the proximate composition respectively. Yuqi et al. (2014) stated that the puffer fish, Leiodon cutcutia is a good source of three minerals viz., calcium, phosphorous and iron.

From the above findings, it is clear that both Leiodon cutcutia and Dichotomyctere fluviatilis have the nutritional value like other edible fin fishes, but their main problem is the presence of Tetrodotoxin (TTX) which is deadly for human being (Kiernan et al., 2005). So, if the risk of this toxin can be eliminated from the fish muscle before cooking then the studied two puffer species can be used as significant fish protein sources. Government and private fisheries sectors and institutions should look forward to solve the problem with puffer fish toxin. Thus, further research towards sustainable management, conservation and biosecurity issues will lead to flourish blue economy.

\section{REFERENCES}

Association of Official Analytical Chemists (AOAC), 1975. Changes in Official Methods of Analysis.: Supplement to 12th Edition, Official Methods of Analysis. 1st-1975. 
Azman, A., Samsur, M., Mohammed, M., Shabdin, M. L. and Fasihuddin, B. A. 2015. Assessment of proximate composition and tetrodotoxin content in the muscle of Yellow puffer fish, Xenopterus naritus (Richardson 1848) from Sarawak, Malaysia. International Food Research Journal, 22(6).

Eswar, A., Kathirvel, K., Anbarasu, R., Ramamoorthy, K., Sankar, G., Suvitha, S. and Manikandarajan, T. 2014. Proximate composition and fatty acid analysis of puffer fish, Lagocephalus inermis (Temminck and Schlegel, 1850) and Lagocephalus lunaris (Bloch and Schneider, 1801) from Parangipettai, Southeast coast of India. International Letters of Natural Sciences, 12(1).

Folch, J., Lees, M. and Sloane Stanley, G. H. 1957. A simple method for the isolation and purification of total lipids from animal tissues. J. biol Chem, 226(1), 497-509.

Islam, M. R., Chowdhury, F. R., Das, S. K., Rahman, S. M. M., and Amin, M. R. 2018. Outbreak of puffer fish poisoning in Dhaka City. Journal of Medicine, 19(1), 30-34.

Kiernan, M. C., Isbister, G. K., Lin, C. S. Y., Burke, D. and Bostock, H. 2005. Acute tetrodotoxin-induced neurotoxicity after ingestion of puffer fish. Annals of neurology, 57(3), 339-348.

Nandeesha, M. C., Gangadhar, B., Varghese, T. J. and Keshavanath, P. 1998. Effect of feeding Spirulina platensis on the growth, proximate composition and organoleptic quality of common carp, Cyprinus carpio L. Aquaculture Research, 29(5), 305-312.

Ray, S., Ahmed, M. I., Khatun, M. M., Sayeed, M. A. B., Shah, M. S. and Sarower, M. G. 2014. Antioxidant potential and nutrient content of selected small indigenous species of fish. Pharmacology Online, 2, 48-53.

Santini, F., Nguyen, M. T. T., Sorenson, L., Waltzek, T. B., Lynch Alfaro, J. W., Eastman, J. M. and Alfaro, M. E. 2013. Do habitat shifts drive diversification in teleost fishes? An example from the puffer fishes (Leiodontidae). Journal of Evolutionary Biology, 26(5), 1003-1018.

Shamsuzzaman, M. M., Islam, M. M., Tania, N. J., Al-Mamun, M. A., Barman, P. P. and Xu, X. 2017. Fisheries resources of Bangladesh: Present status and future direction. Aquaculture and Fisheries, 2(4), 145-156.

Yuqi, L., Liya, W. and Ningping, T. 2014. Analysis and evaluation of nutritional composition of farmed male puffer fish (Takifugu obscurus). In SHS Web of Conferences (Vol. 6, p. 03010). EDP Sciences. 